\title{
Annual Report of the Korean Association of External Quality Assessment Service on Transfusion Medicine (2020)
}

\author{
Hee-Jeong Youk ${ }^{1 \oplus}$, Jin Seok Kim ${ }^{1 \oplus}$, John Jeongseok Yang ${ }^{1 \oplus}$, Hyungsuk Kim² ${ }^{\circledR}$, and Dae-Hyun Ko ${ }^{1 \oplus}$ \\ ${ }^{1}$ Department of Laboratory Medicine, Asan Medical Center, University of Ulsan College of Medicine; ${ }^{2}$ Department of Laboratory \\ Medicine, Seoul National University Hospital, Seoul, Korea
}

\section{Corresponding author: \\ Dae-Hyun Ko \\ Department of Laboratory Medicine, Asan Medical Center, University of Ulsan College of Medicine, 88 Olympic-ro 43- gil, Songpa-gu, Seoul 05505, Korea Tel +82-2-3010-4504 \\ E-mail daehyuni1118@amc.seoul.kr}

\section{Co-corresponding author:}

Hyungsuk Kim

Department of Laboratory Medicine, Seoul National University Hospital, 101 Daehak-ro, Jongno-gu, Seoul 03080, Korea

Tel +82-2-2072-3500

E-mail hyungsuk_kim@snuh.org

This is an Open Access article distributed under the terms of the Creative Commons Attribution Non-Commercial License (http://creativecommons.org/licenses/ by-nc/4.0) which permits unrestricted non-commercial use, distribution, and reproduction in any medium, provided the original work is properly cited.
This report summarizes the 2020 survey results of the external quality assessment (EQA) scheme for the Transfusion Medicine Program (TMP) in Korea. Proficiency testing materials were prepared at Asan Medical Center for biannual distribution to the participating laboratories. The accuracy rates and number of participants for the 10 survey items were as follows: ABO typing, 99.6\%-99.9\% ( $n=890 / 897)$; RhD typing, 99.7\%-100.0\% ( $n=877 / 885)$; crossmatching, $94.0 \%-99.1 \%(n=771 / 780) ;$ ABO subgroup typing, 95.2\%-98.4\% ( $n=62 / 63$ ); Rh CcEe antigen, $100 \%$ ( $n=56 / 58)$; weak D test, $92.8 \%-98.4 \%(n=250 / 252)$; antibody screening, $99.7 \%-100.0 \%$ ( $n=327 / 329)$; direct antiglobulin test (DAT) using a polyspecific reagent, 97.2\%-99.7\% ( $n=283 / 286$ ); DAT using anti-immunoglobulin-G monospecific reagent, $88.7 \%-100.0 \%(n=71 / 71)$; DAT using anti-C3d monospecific reagent, 97.2\%-100.0\% ( $n=70 / 72$ ); antibody identification, $68.9 \%-100 \%$ ( $n=135 / 135)$; and $A B O$ antibody titration, $94.3 \%-100.0 \%(n=140 / 142)$. As compared to last year's EQA report, there was an average increase of $5.1 \%$ in the number of participating laboratories across the 10 survey items, with the $A B O$ subgroup typing and weak $D$ test showing the highest increase of $8.6 \%$. Although the overall results were excellent, only $68.9 \%$ of the participants precisely detected samples with anti-C and anti-e in the EQA conducted in the first half of 2020. The 2020 EQA scheme for TMP has contributed to the improvement and maintenance of the participating laboratories in the program.

(Lab Med Qual Assur 2021;43:167-75)

Key Words Transfusion medicine, Quality improvement, Laboratory proficiency testing

\section{서론}

수혈 전 검사는 안전한 수혈을 위한 가장 기본적인 요소로 검사 에 오류가 있을 때에는 환자의 생명을 직접 위협할 수 있다. 일반 적으로 수혈 전 검사는 대부분의 의료기관에서 환자의 적혈구와 혈장 혹은 혈청, 그리고 수혈용 혈액제제의 혈구를 이용하여 응집 반응을 보는 검사를 시행하며 아직 많은 검사가 수기법으로 시행
되고 있다. 수기법은 검사과정에서 여러 오류의 가능성을 배제할 수 없으며 검사결과의 편차도 큰 편이다. 따라서 수혈의학 분야 검 사의 외부정도관리는 검사의 신뢰도를 평가하기 위한 매우 중요한 과정이라고 할 수 있다.

국내에서는 대한임상검사정도관리협회에서 임상검사실의 외 부정도관리를 주도적으로 시행하고 있으며, 수혈의학 분야에는 다음과 같은 검사항목에 대해 신빙도조사사업을 시행하고 있다 
[1]. (1) 일반수혈검사: ABO typing (ABO 혈액형검사), blood crossmatching(교차시험), RhD typing (RhD 혈액형검사), (2) 수혈항원검사, 특수: $\mathrm{ABO}$ subgroup typing (ABO 혈액형 아형검사), Rh CcEe antigen test (Rh CcEe 항원검사), weak D test(약-D검사), (3) 수혈항체검사, 일반: direct antiglobulin test(직접항글로불린검사), unexpected antibody-screening(비예기항체 선별검사), (4) 수혈항체검사, 특수: $\mathrm{ABO}$ $\mathrm{Ab}$ titration ( $\mathrm{ABO}$ 항체역가검사), unexpected antibodyidentification(비예기항체 동정검사). 2020년 신빙도조사는 예 년과 같이 1차와 2차에 걸쳐 총 2회 시행되었으며, 2차에 Duffy/ Lewis/Kidd 항원검사에 대한 시범사업이 동시에 이루어졌다. 이 에 저자들은 2020년에 실시한 수혈의학분야 신빙도조사사업 결 과를 분석하여 보고하고자 한다.

\section{재료 및 방법}

\section{1. 조사항목}

서론에서 언급된 $\mathrm{ABO}$ 혈액형검사, 교차시험, $\mathrm{RhD}$ 혈액형검사, $\mathrm{ABO}$ 혈액형아형검사, Rh CcEe 항원검사, 약-D검사, 직접항글로 불린검사, 비예기항체 선별검사, $\mathrm{ABO}$ 항체 역가검사, 비예기항체 동정검사 항목에 대해 신빙도조사를 실시하였다.

\section{2. 신빙도조사 물질 제조}

신빙도조사에 사용된 검체는 대한임상검사정도관리협회의 2020년도 신빙도조사사업 자가제조 정도관리물질 연구용역과제 의 지원을 받아 서울아산병원에서 제조되었다. 검체 제조에 사용 된 혈액제제들은 서울아산병원의 연구윤리심의위원회를 통과한 후 대한적십자사, 한마음혈액원, 서울대학교병원으로부터 심의를 득한 후에 사용하였다(IRB no., 2019-1632, E-2003-077-1108). 서울아산병원에서 제조된 검체는 분주 후 식별 표식을 부착한 뒤 대한임상검사정도관리협회로 납품되었고 개별 포장되어 각 참여 기관으로 발송되었다. 외부신빙도조사 검체는 2020년 5월 11 일에 1 차, 2020년 10 월 26 일에 각각 발송하였다. 참여기관의 검사결과 는 차세대 신빙도조사사업 홈페이지를 통해 입력하도록 하였다.

\section{1) 적혈구 부유액 제조}

적혈구 부유액은 목적하고자 하는 혈액형을 가진 혈액을 Alsever's solution (CE-immundiagnostik AG, Bensheim, Germany)을 사용하여 희석하여 제조하였고, 신빙도조사 검사항 목(각 회차당 검체 수)인 $\mathrm{ABO}$ 혈액형의 혈구형검사(3개), $\mathrm{RhD}$ 혈 액형(3개), $\mathrm{ABO}$ 혈액형아형검사(1개), Rh CcEe 항원검사(1개), 그리고 약-D검사(1개)를 위해 사용되었다. 적혈구 부유액은 2 회차
에서만 시범항목으로 Duffy 항원검사(1개), Lewis 항원검사(1개), Kidd 항원검사(1개)에서 사용되었다. 적혈구 부유액은 $\mathrm{ABO}$ 혈액 형의 혈구형검사와 $\mathrm{RhD}$ 혈액형검사 시에 자동화장비에도 사용이 가능하도록 제작하였는데, 신선동결혈장과 Alsever's solution으 로 희석하여 $20 \%$ 의 재조합 전혈을 만들었고, $\mathrm{ABO}$ 혈액형아형검 사, Rh CcEe 항원검사 그리고 약-D검사용 적혈구 부유액은 $10 \%$ 재조합 전혈을 만들었다. 교차시험용 적혈구 부유액은 $\mathrm{ABO}$ 혈액 형의 혈구형검사용 검체 3개 중 하나를 사용하였고 CPDA (citrate phosphate dextrose adenine)-1 항응고제와 SAG-M (saline adenine glucose mannitol) 보존제를 사용한 혈액백으로부터 분리된 농축적혈구를 사용하였다[1-3].

\section{2) 혈장용 검체 제조}

$\mathrm{ABO}$ 혈청형검사용 혈장은 혈구형과 동일한 $\mathrm{ABO}$ 혈액형, $\mathrm{ABO}$ 항체 역가검사용 혈장은 O형의 신선동결혈장을 사용하였다. 혈액 백의 혼주 시는 무균봉합기로 연결하여 혼합한 뒤에 분주를 진행 하였다[1].

\section{3) 재조합 혈장 검체 제조}

항혈청을 신선동결혈장으로 희석하여 재조합 혈장 검체를 제조 하였고 신빙도조사 검사항목(각 회차당 검체 수)인 교차시험(3개), 비예기항체 선별검사(3개) 그리고 비예기항체 동정검사(2개)를 위 해 사용되었다. 교차시험의 양성 검체는 항혈청을 희석하여 제조 하였으며, 항글로불린 단계에서만 검출되도록 하였다[1].

비예기항체 선별 및 동정용 양성 검체는 1 회차에는 anti-C \& $\mathrm{e}$, anti-M, 2회차에는 anti-E, anti-D를 발송하였다. 각 검체는 항혈청 시약을 사용하여 희석하였는데, 이때 사용된 항혈청 시약 의 종류는 단클론성 anti-C (Diagast, Loos, France), 단클론성 anti-e (Diagast), 단클론성 anti-M (Diagast), 단클론성 anti-E (Diagast), 다클론성 anti-D (Diagast)였다. 혈장 검체의 희석은 $\mathrm{AB}$ 혈액형의 신선동결혈장을 사용하였다[1].

\section{4) 직접항글로불린검사용 혈구 제조}

1 차에서 사용한 직접항글로불린검사용 양성 검체는 인간유래 다클론성 anti-D (Diagast)를 사용하여 인위적으로 감작시킨 혈 구가 사용되었다. 직접항글로불린검사용 음성 검체는 음성결과가 확인된 적혈구가 사용되었다. 2차에서 사용한 직접항글로불린검 사용 immunoglobulin G (IgG), C3d 양성 검체는 여러 명의 환 자의 혈구 검체만을 모아 5 회 세척 후 제조하였으며, $\operatorname{lgG}$ 만 양성 검체는 인간유래 다클론성 anti-D를 사용하여 인위적으로 감작 시킨 혈구가 사용되었다. 혈구의 희석은 혈구보존액인 Alsever's solution을 사용해 3\%-5\%로 희석한 뒤 사용되었다. 


\section{3. 결과 판정 및 분석}

일반수혈검사의 $\mathrm{ABO}$ 혈액형, $\mathrm{RhD}$ 혈액형의 경우 최종 판정과 응집강도 모두에 대하여 평가를 실시하였다. 교차시험의 경우 검 사방법에 따른 혈구 응집강도는 의도한 범위를 보고서에 제공하였 으나 education 항목(code 520)으로 분류하여 평가에서 제외하 였다. 일반 수혈항체검사에서의 직접항글로불린검사 항목은 최종 판정결과에 대해서만 평가하였으며 응집강도는 마찬가지로 code 520 (education 항목)으로 평가에서 제외하였다. 수혈 특수항 원검사는 최종 판정결과에 대해서만 평가하였으며, 응집강도는 code 520을 적용해 평가에서 제외하였다. 수혈 특수항체검사 중 $\mathrm{ABO}$ 항체 역가검사의 경우 최빈값 \pm 1 등급에 해당되는 결과값 빈도의 합이 $80 \%$ 이상인 경우 이를 정답으로 판정하였고, $80 \%$ 미만인 경우 이웃한 등급의 빈도가 큰 것을 계속 합하여 빈도의 합 이 $80 \%$ 가 넘으면 확장한 범위를 정답으로 판정하였으며, 검사방 법별로 참여기관이 10 개 미만인 경우 code 501 을 적용해 평가를 시행하지 않았다. 비예기항체 동정검사는 의도된 정답과 동일하게 보고한 경우에만 적합하다고 판정하였다. 일반 수혈항체검사는 응 집강도와 최종 판정을 모두 보고하였지만, 최종 결과에 대한 평가 만 실시하고 응집강도는 code 520으로 처리하였다.

\section{결과}

\section{1. 일반수혈검사}

\section{1) $\mathrm{ABO}$ 와 RhD 혈액형}

$\mathrm{ABO}$ 혈액형검사는 1 차와 2 차에 걸쳐 총 6 개의 검체를 통해 평 가를 하였으며 정답률은 99.6\%-99.9\% 수준이었다(Table 1). $\mathrm{RhD}$ 혈액형검사도 2차에 걸쳐 총 6 개의 검체로 실시하였고, 정답 률은 99.7\%-100.0\% 수준이었다(Table 2). 예년과 같이 대부분 의 검사실에서 두 가지 검사항목에 대해 오류 없이 수행되고 있는 것으로 판단되었다.

\section{2) 교차시험}

교차시험검사는 2차에 걸쳐 총 6종류의 검체 조합을 시험하였 으며, 적합 검체는 97.3\%-99.1\%, 부적합 검체는 94.0\%-94.8\% 수준의 정답률을 보였다(Table 3). 정답률이 낮은 부적합 검체 조합에서는 시험관법의 식염수법과 $37^{\circ} \mathrm{C}$ 알부민법, $37^{\circ} \mathrm{C}$ lowionic strength saline (LISS)법, 및 LISS법에서 대부분의 기관에 서 음성으로 보고하였다. 시험관법 항글로불린법을 사용하는 기관 과 원주응집법을 사용하는 기관에서는 대부분 $1+$ 이상의 응집을 보고하였다.

Table 1. Number (\%) of participating laboratories in the proficiency tests for ABO blood grouping in 2020

\begin{tabular}{|c|c|c|c|c|c|c|c|c|}
\hline Trial & Specimen & Total & A & B & $A B$ & 0 & Discrepancy & $\begin{array}{l}\text { Intended } \\
\text { response }\end{array}$ \\
\hline \multirow[t]{3}{*}{$1 s t$} & BB-20-01 & $890(100.0)$ & 0 & 887 (99.7) & 0 & 0 & $3(0.3)$ & B \\
\hline & BB-20-02 & $890(100.0)$ & 0 & 0 & 0 & $888(99.8)$ & $2(0.2)$ & 0 \\
\hline & BB-20-03 & $890(100.0)$ & $888(99.8)$ & 0 & 0 & 0 & $2(0.2)$ & $A$ \\
\hline \multirow[t]{3}{*}{ 2nd } & BB-20-07 & $897(100.0)$ & $1(0.1)$ & 0 & 896 (99.9) & 0 & 0 & $A B$ \\
\hline & BB-20-08 & $897(100.0)$ & 0 & 0 & 0 & $895(99.8)$ & $2(0.2)$ & 0 \\
\hline & BB-20-09 & $897(100.0)$ & $1(0.1)$ & 893 (99.6) & 0 & 0 & $3(0.3)$ & B \\
\hline
\end{tabular}

Table 2. Number (\%) of participating laboratories in the proficiency tests for RhD typing in 2020

\begin{tabular}{|c|c|c|c|c|c|c|}
\hline Trial & Specimen & Total & Negative & Variant & Positive & Intended response \\
\hline \multirow[t]{3}{*}{$1 s t$} & BB-20-01 & $877(100.0)$ & 0 & 0 & $877(100.0)$ & Positive \\
\hline & BB-20-02 & $877(100.0)$ & 0 & 0 & $877(100.0)$ & Positive \\
\hline & BB-20-03 & 877 (100.0) & 0 & 0 & $877(100.0)$ & Positive \\
\hline \multirow[t]{3}{*}{ 2nd } & BB-20-07 & $885(100.0)$ & $882(99.7)$ & $2(0.2)$ & $1(0.1)$ & Negative \\
\hline & BB-20-08 & $885(100.0)$ & $2(0.2)$ & 0 & $883(99.8)$ & Positive \\
\hline & BB-20-09 & $884(100.0)$ & 0 & 0 & $884(100.0)$ & Positive \\
\hline
\end{tabular}




\section{2. 수혈 특수항원검사}

\section{1) $A B O$ 혈액형아형검사}

1 차 검체는 $\mathrm{A}_{2} \mathrm{Bw}$ 형으로 정답률은 $95.2 \%$ (59/62)였다. 항-A1 시약과의 반응에서 모든 기관이 음성으로 판정하였으나 $\mathrm{A}$ 항원형 을 최종 판정에서 2 기관이 $\mathrm{A}_{1}$ 으로 잘못 판정하여 최종 혈액형 보 고를 $\mathrm{A}_{1} \mathrm{BW}$ 로 하였고, $\mathrm{B}$ 항원형에 대해서는 한 기관에서 $\mathrm{B}$ 아형으 로 판정하지 못하여 $\mathrm{A}_{2} \mathrm{~B}$ 형으로 보고하여 오답으로 판정되었다. 2 차 검체도 $\mathrm{A}_{2} \mathrm{Bw}$ 형으로 정답률은 $98.4 \%$ (62/63)였다. 시험관법 을 사용하는 한 기관에서 항-B 시약과의 반응을 $4+$ 로 판정하여 최
종 판정을 $\mathrm{A}_{2} \mathrm{~B}$ 로 보고하여 오답 판정을 받았고, 그 외 기관은 모두 의도된 정답대로 보고하였다(Table 4).

\section{2) Rh CcEe 항원검사}

$\mathrm{Rh}$ CcEe 항원검사는 1 차에 57 개와 2차에 59 개 기관이 참여하 였다. 1차와 2차 모두 CcEe 표현형의 적혈구 검체가 발송되었으 며, 개별 항원에 대한 혈구응집반응 결과는 입력하였으나 최종판 정을 입력하지 않은 1 개 기관을 제외한 나머지 모든 기관이 1 차와 2차에서 $100 \%$ 정답으로 답변하였다(Table 5).

Table 3. Number (\%) of participating laboratories in the proficiency tests for blood crossmatching

\begin{tabular}{lcccc}
\hline Trial & Specimen & Compatible & Incompatible & Intended response \\
\hline \multirow{2}{*}{ 1st } & BB-20-02+BB-20-04 & $40(5.2)$ & $731(94.8)$ & Incompatible \\
& BB-20-02 + BB-20-05 & $43(5.6)$ & $728(94.4)$ & Incompatible \\
\multirow{2}{*}{ 2nd } & BB-20-02 + BB-20-06 & $764(99.1)$ & $7(0.9)$ & Compatible \\
& BB-20-08+BB-20-10 & $47(6.0)$ & $733(94.0)$ & Incompatible \\
& BB-20-08+BB-20-11 & $759(97.3)$ & $21(2.7)$ & Compatible \\
& BB-20-08+BB-20-12 & $765(98.1)$ & $15(1.9)$ & Compatible \\
\hline
\end{tabular}

Table 4. Number (\%) of participating laboratories in the proficiency tests for ABO subgroup typing

\begin{tabular}{|c|c|c|c|c|c|c|c|}
\hline \multirow{3}{*}{$\begin{array}{l}\text { Trial (specimen) } \\
\text { 1st (BGS-20-01) }\end{array}$} & \multirow{3}{*}{$\begin{array}{l}\text { Category } \\
\text { No. }\end{array}$} & \multicolumn{4}{|c|}{ Anti-sera } & \multirow{2}{*}{\multicolumn{2}{|c|}{$A B O$ subgroup }} \\
\hline & & \multirow{2}{*}{$\begin{array}{c}\text { Anti-A } \\
62\end{array}$} & \multirow{2}{*}{$\begin{array}{c}\text { Anti-B } \\
62\end{array}$} & \multirow{2}{*}{$\begin{array}{c}\text { Anti- } A_{1} \\
62\end{array}$} & \multirow{2}{*}{$\begin{array}{c}\text { Anti-H } \\
60\end{array}$} & & \\
\hline & & & & & & $\mathrm{A}_{1} \mathrm{Bw}$ & $2(3.2)^{\star}$ \\
\hline & Negative & & & $62(100)$ & & $\mathrm{A}_{2} \mathrm{~B}$ & $1(1.6)^{\star}$ \\
\hline & \pm & & $1(1.6)$ & & & $\mathrm{A}_{2} \mathrm{Bw}$ & $59(95.2$ \\
\hline & $1+$ & & $9(14.5)$ & & & & \\
\hline & $2+$ & & $22(35.5)$ & & $3(5.0)$ & & \\
\hline & $3+$ & $2(3.2)$ & $12(19.4)$ & & $24(40.0)$ & & \\
\hline & $4+$ & $60(96.8)$ & & & $33(55.0)$ & & \\
\hline & MF & & $18(29.0)$ & & & & \\
\hline \multirow[t]{8}{*}{ 2nd (BGS-20-04) } & No. & 63 & 63 & 59 & 62 & $\mathrm{~A}_{2} \mathrm{~B}$ & $1(1.6)^{\star}$ \\
\hline & Negative & & & $63(100.0)$ & & $\mathrm{A}_{2} \mathrm{Bw}$ & $62(98.4$ \\
\hline & \pm & & & & & & \\
\hline & $1+$ & & $8(12.7)$ & & $2(3.2)$ & & \\
\hline & $2+$ & & $23(36.5)$ & & $25(40.3)$ & & \\
\hline & $3+$ & & $6(9.5)$ & & $21(33.9)$ & & \\
\hline & $4+$ & $63(100.0)$ & $1(1.6)$ & & $14(22.6)$ & & \\
\hline & MF & & $25(39.7)$ & & & & \\
\hline
\end{tabular}

Abbreviation: MF, mixed field agglutination.

*Unacceptable responses for $\mathrm{ABO}$ subgrouping. 


\section{3) 약-D검사}

2020년에 발송된 약-D검사 검체는 1 차와 2 차 모두 변이형 D형 검체였다. 1 차에 발송된 검체에 대하여 232 기관(92.8\%)이 최종 적으로 $\mathrm{D}$ 변이형을 보고하였고, $\mathrm{D}$ 음성, $\mathrm{D}$ 양성으로 보고한 기관 이 각각 2 기관(0.8\%), 16 기관(6.4\%)이었다. 2차 검체에서는 248 기관(98.4\%)에서 D변이형을 제대로 판정하였으며 1 기관 $(0.4 \%)$ 은 D 양성, 3 기관(1.2\%)은 D 음성으로 판정하였다(Table 6).

\section{3. 일반 수혈항체검사}

\section{1) 비예기항체 선별검사}

비예기항체 선별검사에는 1 차 327 개, 2 차 329 개 기관이 각 각 참여하였으며, 1 차에서는 양성 검체 1 개와 음성 검체 2 개, 2 차에서는 양성 검체 2 개와 음성 검체 1 개를 발송하였다. 1 차에서 BBG-20-02 검체를 양성으로 보고한 한 기관을 제외하고는 모두 의도한 정답을 맞추었다(Table 7).

Table 5. Number (\%) of participating laboratories in the proficiency tests for Rh CcEe antigen typing

\begin{tabular}{|c|c|c|c|c|c|c|c|}
\hline \multirow{3}{*}{$\begin{array}{l}\text { Trial (specimen) } \\
\text { 1st (BGS-20-02) }\end{array}$} & \multirow{3}{*}{$\begin{array}{l}\text { Category } \\
\text { No. }\end{array}$} & \multicolumn{4}{|c|}{ Antigen } & \multirow{2}{*}{\multicolumn{2}{|c|}{ Rh CcEe type }} \\
\hline & & \multirow{2}{*}{$\begin{array}{c}\mathrm{C} \\
57\end{array}$} & \multirow{2}{*}{$\begin{array}{c}\mathrm{E} \\
57\end{array}$} & \multirow{2}{*}{$\begin{array}{c}\mathrm{C} \\
57\end{array}$} & \multirow{2}{*}{$\begin{array}{c}\mathrm{e} \\
57\end{array}$} & & \\
\hline & & & & & & $\mathrm{CcEe}$ & $56(100.0)$ \\
\hline & Negative & & & & & & \\
\hline & $1+$ & & & & & & \\
\hline & $2+$ & & $2(3.5)$ & $1(1.8)$ & $1(1.8)$ & & \\
\hline & $3+$ & $22(38.6)$ & $19(33.3)$ & $15(26.3)$ & $28(49.1)$ & & \\
\hline & $4+$ & $35(61.4)$ & $36(63.2)$ & $41(71.9)$ & $28(49.1)$ & & \\
\hline \multirow[t]{6}{*}{ 2nd (BGS-20-05) } & No. & 59 & 59 & 59 & 59 & CcEe & $58(100.0)$ \\
\hline & Negative & & & & & & \\
\hline & $1+$ & & & & & & \\
\hline & $2+$ & $5(8.5)$ & $4(6.8)$ & $1(1.7)$ & $6(10.2)$ & & \\
\hline & $3+$ & $18(30.5)$ & $17(28.8)$ & $21(35.6)$ & $27(45.8)$ & & \\
\hline & $4+$ & $36(61.0)$ & 38 (64.4) & $37(62.7)$ & $26(44.1)$ & & \\
\hline
\end{tabular}

Table 6. Number (\%) of participating laboratories in the proficiency tests for the weak D test

\begin{tabular}{|c|c|c|c|c|}
\hline \multirow{2}{*}{ Trial (specimen) } & \multicolumn{2}{|c|}{ BGS-20-03 } & \multicolumn{2}{|c|}{ BGS-20-06 } \\
\hline & Anti-D (Rh typing) & Ani-D (weak D test) & Anti-D (Rh typing) & Ani-D (weak D test) \\
\hline No. & 247 & 249 & 248 & 251 \\
\hline Negative & 236 (95.5) & $3(1.2)$ & $243(98.0)$ & $1(0.4)$ \\
\hline \pm & $5(2.0)$ & $1(0.4)$ & $3(1.2)$ & $1(0.4)$ \\
\hline $1+$ & $4(1.6)$ & $24(9.6)$ & $2(0.8)$ & $19(7.6)$ \\
\hline $2+$ & $1(0.4)$ & $66(26.5)$ & - & $62(24.7)$ \\
\hline $3+$ & - & $87(34.9)$ & - & $106(42.2)$ \\
\hline $4+$ & $1(0.4)$ & $68(27.3)$ & - & $62(24.7)$ \\
\hline NT & - & - & - & - \\
\hline D positive & \multicolumn{2}{|c|}{$16(6.4)^{*}$} & \multicolumn{2}{|c|}{$1(0.4)^{*}$} \\
\hline D variant & \multicolumn{2}{|c|}{$232(92.8)$} & \multicolumn{2}{|c|}{$248(98.4)$} \\
\hline D negative & \multicolumn{2}{|c|}{$2(0.8)^{\star}$} & \multicolumn{2}{|c|}{$3(1.2)^{\star}$} \\
\hline
\end{tabular}

Abbreviation: NT, not tested.

*Unacceptable responses for weak D testing. 
Table 7. Number (\%) of participating laboratories in the proficiency tests for antibody screening

\begin{tabular}{|c|c|c|c|c|c|}
\hline Trial & Specimen & No. of laboratories & Negative & Positive & Intended response \\
\hline \multirow[t]{3}{*}{$1 s t$} & BBG-20-01 & $327(100.0)$ & 0 & $327(100.0)$ & Positive \\
\hline & BBG-20-02 & $327(100.0)$ & $326(99.7)$ & $1(0.3)^{\star}$ & Negative \\
\hline & BBG-20-03 & $327(100.0)$ & $327(100.0)$ & 0 & Negative \\
\hline \multirow[t]{3}{*}{ 2nd } & BBG-20-07 & $329(100.0)$ & 0 & $329(100.0)$ & Positive \\
\hline & BBG-20-08 & $329(100.0)$ & $329(100.0)$ & 0 & Negative \\
\hline & BBG-20-09 & $327(100.0)$ & 0 & $329(100.0)$ & Positive \\
\hline
\end{tabular}

*Unacceptable responses for antibody screening.

Table 8. Number (\%) of participating laboratories in the proficiency tests for the direct antiglobulin test

\begin{tabular}{|c|c|c|c|c|c|c|}
\hline Trial & Antiglobulin & Specimen & No. of laboratories & Negative & Positive & Intended response \\
\hline \multirow[t]{9}{*}{$1 \mathrm{st}$} & Polyspecific & BBG-20-04 & $283(100.0)$ & $3(1.1)$ & $280(98.9)$ & Positive \\
\hline & & BBG-20-05 & $283(100.0)$ & $279(98.6)$ & $4(1.4)$ & Negative \\
\hline & & BBG-20-06 & $283(100.0)$ & $275(97.2)$ & $8(2.8)$ & Negative \\
\hline & Anti-IgG & BBG-20-04 & $71(100.0)$ & 0 & $71(100.0)$ & Positive \\
\hline & & BBG-20-05 & $71(100.0)$ & $71(100.0)$ & 0 & Negative \\
\hline & & BBG-20-06 & $71(100.0)$ & $71(100.0)$ & 0 & Negative \\
\hline & Anti-C3d & BBG-20-04 & $70(100.0)$ & $69(98.6)$ & $1(1.4)$ & Negative \\
\hline & & BBG-20-05 & $70(100.0)$ & $70(100.0)$ & 0 & Negative \\
\hline & & BBG-20-06 & $70(100.0)$ & $70(100.0)$ & 0 & Negative \\
\hline \multirow[t]{9}{*}{$2 n d$} & Polyspecific & BBG-20-10 & $286(100.0)$ & $3(1.0)$ & $283(99.0)$ & Positive \\
\hline & & BBG-20-11 & $286(100.0)$ & $3(1.0)$ & $283(99.0)$ & Positive \\
\hline & & BBG-20-12 & $286(100.0)$ & $285(99.7)$ & $1(0.3)$ & Negative \\
\hline & Anti-IgG & BBG-20-10 & $71(100.0)$ & $8(11.3)$ & $63(88.7)$ & Positive \\
\hline & & BBG-20-11 & $71(100.0)$ & $1(1.4)$ & 70 (98.6) & Positive \\
\hline & & BBG-20-12 & $71(100.0)$ & $71(100.0)$ & 0 & Negative \\
\hline & Anti-C3d & BBG-20-10 & $72(100.0)$ & 0 & $72(100.0)$ & Positive \\
\hline & & BBG-20-11 & $72(100.0)$ & $70(97.2)$ & $2(2.8)$ & Negative \\
\hline & & BBG-20-12 & $72(100.0)$ & $72(100.0)$ & 0 & Negative \\
\hline
\end{tabular}

Abbreviation: Ig, immunoglobulin.

Table 9. Number (\%) of participating laboratories in the proficiency tests for unexpected antibody identification

\begin{tabular}{|c|c|c|c|c|c|}
\hline \multirow{2}{*}{ Trial } & \multirow{2}{*}{ Specimen } & \multirow{2}{*}{ No. } & \multicolumn{2}{|c|}{ Intended response } & \multirow{2}{*}{ Other responses (no. of participants) } \\
\hline & & & Result & No. $(\%)$ & \\
\hline \multirow[t]{2}{*}{1 st } & BBS-20-01 & 135 & Anti-C+anti-e & $93(68.9)$ & Anti-C (2), anti-e (39), anti-C+others (1) \\
\hline & BBS-20-02 & 135 & Anti-M & $134(99.3)$ & Anti-Leb (1) \\
\hline \multirow[t]{2}{*}{ 2nd } & BBS-20-04 & 135 & Anti-E & $133(98.5)$ & Anti-c+anti-E (2) \\
\hline & BBS-20-05 & 135 & Anti-D & $155(100.0)$ & Not applicable \\
\hline
\end{tabular}


Table 10. Number of participating laboratories according to the technique for ABO antibody titration

\begin{tabular}{|c|c|c|c|c|c|c|c|c|c|c|c|c|}
\hline \multirow{2}{*}{ Trial } & \multirow{2}{*}{ Technique } & \multirow{2}{*}{ No. } & \multirow{2}{*}{$\begin{array}{c}\text { Acceptable } \\
\text { range (\%) }\end{array}$} & \multicolumn{9}{|c|}{ Titer } \\
\hline & & & & 4 & 8 & 16 & 32 & 64 & 128 & 256 & 512 & 1024 \\
\hline \multicolumn{13}{|l|}{ Anti-A } \\
\hline \multirow[t]{9}{*}{ 1st (BBS-20-03) } & Tube-IS & 38 & 97.4 & & & 2 & 20 & 15 & 1 & & & \\
\hline & Tube-RT & 22 & 100.0 & & & & 6 & 14 & 2 & & & \\
\hline & Tube-AHG & 21 & 100.0 & & & & & 4 & 13 & 4 & & \\
\hline & Tube-AHG+DTT & 5 & NA & & & & & 1 & & 3 & 1 & \\
\hline & CAT-RT & 15 & 100.0 & & & & & 15 & & & & \\
\hline & CAT-AHG & 33 & 100.0 & & & & & 1 & 16 & 16 & & \\
\hline & CAT-AHG+DTT & 5 & NA & & & & & & 2 & 3 & & \\
\hline & Others & 1 & NA & & & & 1 & & & & & \\
\hline & Total & 140 & NA & & & 2 & 27 & 50 & 34 & 26 & 1 & \\
\hline \multirow[t]{9}{*}{ 2nd (BBS-20-06) } & Tube-IS & 35 & 94.3 & & & 2 & 18 & 13 & 2 & & & \\
\hline & Tube-RT & 25 & 100.0 & & & & 6 & 17 & 2 & & & \\
\hline & Tube-AHG & 21 & 100.0 & & & & & 5 & 16 & & & \\
\hline & Tube-AHG+DTT & 6 & NA & & & & 2 & 2 & 1 & & & \\
\hline & CAT-RT & 15 & 100.0 & & & & 7 & 8 & & & & \\
\hline & CAT-AHG & 35 & 100.0 & & & & & 5 & 24 & 6 & & \\
\hline & CAT-AHG+DTT & 5 & NA & & & & & 1 & 2 & 2 & & \\
\hline & Others & 1 & NA & & & & 1 & & & & & \\
\hline & Total & 142 & NA & & & 2 & 34 & 51 & 47 & 8 & & \\
\hline \multicolumn{13}{|l|}{ Anti-B } \\
\hline \multirow[t]{9}{*}{ 1st (BBS-20-03) } & Tube-IS & 38 & 97.4 & & 6 & 22 & 9 & 1 & & & & \\
\hline & Tube-RT & 22 & 95.5 & & 1 & 10 & 11 & & & & & \\
\hline & Tube-AHG & 21 & 95.2 & & & 1 & 7 & 12 & 1 & & & \\
\hline & Tube-AHG+DTT & 5 & NA & & & & 1 & 1 & 2 & 1 & & \\
\hline & CAT-RT & 15 & 100.0 & & & 13 & 2 & & & & & \\
\hline & CAT-AHG & 33 & 100.0 & & & & 10 & 17 & 6 & & & \\
\hline & CAT-AHG+DTT & 5 & NA & & & & & 4 & 1 & & & \\
\hline & Others & 1 & NA & & & & 1 & & & & & \\
\hline & Total & 140 & NA & & 7 & 47 & 40 & 35 & 10 & 1 & & \\
\hline \multirow[t]{9}{*}{ 2nd (BBS-20-06) } & Tube-IS & 35 & 97.1 & & & 12 & 17 & 5 & 1 & & & \\
\hline & Tube-RT & 25 & 100.0 & & & 1 & 12 & 12 & & & & \\
\hline & Tube-AHG & 21 & 100.0 & & & & & 1 & 13 & 7 & & \\
\hline & Tube-AHG+DTT & 5 & NA & & & & 2 & 2 & & 1 & & \\
\hline & CAT-RT & 15 & 100.0 & & & 1 & 9 & 5 & & & & \\
\hline & CAT-AHG & 35 & 97.1 & & & & & 1 & 11 & 18 & 5 & \\
\hline & CAT-AHG+DTT & 5 & NA & & & & & 1 & 1 & 2 & 1 & \\
\hline & Others & 1 & NA & & & 1 & & & & & & \\
\hline & Total & 142 & NA & & & 15 & 40 & 27 & 26 & 28 & 6 & \\
\hline
\end{tabular}

Acceptable results are indicated in bold.

Abbreviations: IS, immediate spin; RT, room temperature incubation; AHG, indirect anti-human globulin test; DTT, dithiothreitol; CAT, column agglutination technology; NA, not applicable. 


\section{2) 직접항글로불린검사}

직접항글로불린검사는 1 차와 2 차에 각각 3 개의 검체가 발송되 었다. 다특이성 항글로불린검사, IgG 단특이성 항글로불린검사, C3d 단특이성 항글로불린검사의 정답률은 각각 $97.2 \%-100.0 \%$, $88.7 \%-100.0 \%, 97.2 \%-100.0 \%$ 수준으로 나타났다(Table 8). 2차에서 BBG-20-10 검체는 IgG 단특이성 검사에서 양성을 보이 는 검체였으나 시험관법을 사용하는 기관에서는 절반이 넘는 기관 에서 음성 결과를 보여 검사법 간 차이가 있는 것으로 나타났다.

\section{4. 수혈 특수항체검사}

\section{1) 비예기항체 동정검사}

1 차와 2차 비예기항체 동정검사에는 모두 135 개 기관이 참 여하였고 각 검체별 정답률은 anti-C+anti-e (68.9\%), anti-M (99.3\%), anti-E (98.5\%), 그리고 anti-D (100.0\%)로 확인되었다 (Table 9). Anti-C+anti-e가 출제되었던 BBS-20-01의 경우 정답 률이 상대적으로 낮게 나타났으며, 39개(28.9\%) 기관에서 anti-e 로 결과를 제출해 $\mathrm{Rh}$ 계열 복합항체의 정확한 구분에 대해 다소 취약한 모습을 보여주었다.

\section{2) $A B O$ 항체 역가검사}

1차와 2차에 anti-A와 anti-B 검체가 각각 하나씩 발송되었으 며, 각 검사방법별로 $\mathrm{ABO}$ 항체 역가검사 결과와 허용범위를 굵은 글씨로 표시하여 Table 10에 정리하였다. Anti-A와 anti-B 모두 예년에 비하여 전반적인 정답률이 $94.3 \%-100.0 \%$ 수준으로 향상 된 일치도를 보여주었으며(Table 10), 시험관법의 사용이 점차 줄 고 원주응집법을 사용하는 기관이 점진적으로 증가하는 양상을 보 여주고 있음을 알 수 있었다[1].

\section{고찰}

2020년 수혈의학분야 신빙도조사에 참여한 기관은 예년과 비 교하여 꾸준한 증가 추세를 보여주고 있으며 정답률도 전반적으로 향상되는 양상을 보여주었다. 2020년도 하반기에는 Duffy/Kidd/ Lewis 항원에 대한 시범사업도 같이 진행되었으며, 그 결과에 대 해서는 Chung 등[2]의 보고에서 찾아볼 수 있다.

2020년 수혈 특수항체검사의 비예기항체 동정검사 중 복합항 체가 출제되었던 1회차 BBS-20-01 검체에서 오답률이 높게 나타 났다. 해당 검체는 상용화된 항-C 시약 및 항-e 시약을 이용해서 만든 검체로, 두 항체가 복합적으로 검출되어야 하나 많은 기관에 서 둘 중 하나만 보고하였고, 특히 항-e 항체만 존재한다고 보고한 기관이 $28.9 \%$ (39/135)나 되었다. 이는 상용화된 비예기항체 동
정용 혈구 패널이 대개 C항원만 양성인 혈구는 없고 e항원만 양성 이거나 C항원과 e항원이 동시 양성, 또는 두 항원 다 음성인 혈구 들로만 이루어진 경우가 대부분이기 때문이다. 이러한 경우 e항원 양성인 혈구에 모두 반응한다면 항-e항체만 단독으로 존재하는지 또는 항-C항체와 항-e항체가 같이 존재하는지 구분하기가 어려울 수 있다. 항-C항체와 항-e항체가 공존하는 경우 대부분 C항원이 e 항원과 같이 발현된 세포에서 나머지 e항원만 가진 세포에 비해 응집강도가 더 강하게 나타나는 경우가 많다. 반응강도 차이가 심 한 경우, 항글로불린 단계에서는 항-C항체만 검출이 되고, 항-e항 체는 papain 처리된 혈구에서만 검출되는 경우도 종종 관찰된다. 반면에 위와 같이 C항원이 발현된 세포에서 더 두드러진 응집강 도가 관찰되지 않으면 항-e항체만 존재할 가능성이 높지만, 항-C 항체와 항-e항체가 공존하는 것인지 또는 항-e항체만 존재하는지 두 가지 가능성을 모두 고려해야 하며, 이를 감별하기 위한 추가 적인 조치를 취해야한다[3]. 한 가지 방법은 C+e- 표현형 혈구와 의 응집 여부로 항-C항체의 유무를 확인할 수 있다. 다른 방법으로 는 C-e+ 혈구로 검체를 흡착하여 항-e항체 반응성을 제거시킨 뒤 에 남은 검체로 비예기항체 동정검사를 다시 시행하여 항-C항체 의 유무를 역시 확인할 수 있다. C+e- 또는 C-e+ 표현형의 혈구는 환자 잔여 검체에 항원검사를 시행하여 찾거나 혈액원에서 공급받 은 수혈용 적혈구 중 해당 표현형의 혈액을 찾아 교차시험용 관분 절을 검사에 사용할 수 있다. 그러나 상당수의 검사실에서 추가적 인 검사를 시행하거나 복합항체 여부에 대해 충분히 고려를 하지 않은 채 결과를 보고하는 것으로 보이며, 이는 이전의 신빙도조사 결과에서도 꾸준히 문제가 되어왔던 점이다[1]. 향후 국내 임상검 사실들의 복합항체 감별능력 향상을 위하여 꾸준한 노력이 필요할 것으로 생각된다.

국내 수혈의학분야 외부정도관리 대상 검사들에서, 대부분의 항목은 의도된 정답(intended response)이 있는 경우가 많지만 $\mathrm{ABO}$ 항체 역가검사는 같은 방법을 사용하는 peer group의 최빈 값을 기준으로 하여 평가하고 있다. 이러한 점은 $\mathrm{ABO}$ 항체 역가검 사가 표준화가 되어있지 못하기 때문이나[4-6], 최빈값 자체는 기 관들의 결과 분포를 제대로 반영하는 데에 한계가 있는 값이다[7]. 이에 $\mathrm{ABO}$ 항체 역가검사에서 최빈값이 아닌 다른 기준을 적용하 기 위한 연구가 본 연구진에 의하여 발표된 바가 있으며[7], 국내 외부정도관리에도 $\mathrm{ABO}$ 항체 역가 평가기준 개선에 대한 연구가 본 연구진에 의하여 이루어지고 있으며 그 결과는 조만간 발표될 예정이다.

약-D검사의 경우 현재 다음 세 가지 항목으로 구성되어 있다. (1) 실온 단계에서의 anti-D에 대한 응집반응을 확인하는 Rh typing, (2) 항글로불린 단계에서의 anti-D에 대한 응집반응으로 사전적 의미의 약-D검사, (3) Rh typing과 약-D검사 결과를 바탕 
으로 D 음성, D변이형, D 양성 여부에 대한 최종 판정. 현재 (1) 또 는 (2) 항목을 “미시행”으로 입력을 해도 (3)만 결과를 올바르게 입력하면 정답 판정을 받을 수 있는데, 이는 정답을 도출하는 과정 에서 논리적인 공백 또는 모순이 발생할 수 있는 구조적인 문제가 있다. 또한 $\mathrm{ABO}$ 항체 역가검사의 경우 검사방법별로 참가기관 수 및 일치도에 따라 반정량결과에 대한 정답 판정범위를 설정하고 있는 반면, 약-D검사에서는 (1)과 (2) 항목은 검사방법별로 결과를 입력하게 되어 있으나 최종 판정인 (3) 항목은 검사방법별로 나누 어서 평가가 진행되지 못하고 있다. 약-D 또는 $\mathrm{ABO}$ 아형과 같이 약화된 항원을 대상으로 하는 면역혈액학 검사는 표준물질이 존재 하지 않으며, 검사방법 및 시약에 따라 결과의 일치도가 낮게 나타 날 수 있는 근본적인 특성이 있기 때문에 향후 이와 같은 특수성을 고려해 정답 판정기준 변경에 대한 검토가 필요하다고 생각된다. 또한 현재 신빙도조사사업 프로그램 검사항목의 명칭은 "weak D test"로 명명되어 있으나, 실제 평가를 받는 항목은 (2)가 아닌 (3) 에 대해 이루어지고 있다. 따라서 프로그램 명칭을 실제 평가를 받 는 항목에 맞게 Rh variant typing과 같은 형태로 이름을 수정하 거나, 약-D검사 과정 자체에 더 비중을 두어 (3)이 아닌 (2) 항목에 대해 평가를 받는 형태로 프로그램 구성을 개편하는 것에 대해서 도 고민이 필요하다고 생각된다.
2020년에는 수혈 특수항원검사에서 Duffy/Kidd/Lewis 항원에 대한 시범사업이 이루어졌고, 이를 토대로 2021년에는 세 항원검 사가 정식 종목으로 시행되고 있다. 향후에도 대한임상검사정도관 리협회에서는 향후에도 꾸준히 검사종목 확대를 위하여 노력 중이 며, 2021년에는 anti-D titer에 대한 시범사업이 실시될 예정이다.

\section{감사의 말}

정도관리물질 제조를 위한 혈액 준비에 도움을 주신 대한적십자 사 남부혈액원과 한마음혈액원, 그리고 동결적혈구 보관 및 해동 에 도움을 주신 세브란스병원 혈액은행 관계자분들께 감사드린다.

\section{ORCID}

Hee-Jeong Youk https://orcid.org/0000-0003-3528-7729 Jin Seok Kim https://orcid.org/0000-0003-0166-2084 John Jeongseok Yang

https://orcid.org/0000-0002-7739-1009

Hyungsuk Kim https://orcid.org/0000-0002-0574-9200

Dae-Hyun Ko https://orcid.org/0000-0002-9781-0928

\section{REFERENCES}

1. Yang JJ, Kim JS, Lim YA, Kim H, Ko DH. Annual report of the Korean Association of External Quality Assessment Service on transfusion medicine (2019). Lab Med Qual Assur 2020;42:112-20.

2. Chung Y, Kim JS, Yang JJ, Kim H, Hwang SH, Oh HB, et al. A pilot project for expansion of the external quality assessment program in transfusion medicine: extended antigen typing. Lab Med Qual Assur 2021;43:87-93.

3. Er LS, Bailey DJ. Identification of antibodies to red cell antigens. In: Cohn CS, Delayney M, Johnson ST, Katz LM, editors. Technical manual. 20th ed. Bethesda (MD): American Assocation of Blood Banks, 2020:389-428.

4. AuBuchon JP, de Wildt-Eggen J, Dumont LJ; Biomedical Excellence for Safer Transfusion Collaborative; Transfusion Medicine Resource Committee of the College of American Pathologists. Reducing the variation in performance of antibody titrations. Arch Pathol Lab Med 2008;132:1194-201.

5. Bachegowda LS, Cheng YH, Long T, Shaz BH. Impact of uniform methods on interlaboratory antibody titration variability: antibody titration and uniform methods. Arch Pathol Lab Med 2017;141:131-8.

6. Kang SJ, Lim YA, Baik SY. Comparison of ABO antibody titers on the basis of the antibody detection method used. Ann Lab Med 2014;34:300-6.

7. Yang JJ, Chung Y, Kim H, Ko DH, Hwang SH, Oh HB. Retrospection of anti-blood group antibody proficiency testing data using the geometric mean and standard deviation. Am J Clin Pathol 2020;153:530-6. 